\title{
Oxygen limited thermal tolerance and performance in the lugworm Arenicola marina: A latitudinal comparison
}

\author{
Mareike Schröer $^{\mathrm{a}}$, Astrid C. Wittmann ${ }^{\mathrm{a}}$, Nico Grüner ${ }^{\mathrm{b}}$, Hans-Ulrich Steeger ${ }^{\mathrm{b}}$, Christian Bock ${ }^{\mathrm{a}, *}$, \\ Rüdiger Paul ${ }^{\mathrm{b}}$, Hans-O. Pörtner ${ }^{\mathrm{a}}$ \\ ${ }^{a}$ Marine Animal Physiology, Alfred Wegener Institute for Polar and Marine Research, Am Handelshafen 12, D-27570 Bremerhaven, Germany \\ b Institute for Zoophysiology of the Westfälische Wilhelms University of Münster, Hindenburgplatz 55, D-48143 Münster, Germany
}

\section{A R T I C L E I N F O}

Article history:

Received 25 September 2008

Received in revised form 29 January 2009

Accepted 2 February 2009

\section{Keywords:}

Arenicola marina

Haemoglobin $\mathrm{P}_{50}$

Latitudinal cline

Oxygen consumption

Performance

Thermal adaptation

Thermal tolerance

Ventilation

\begin{abstract}
A B S T R A C T
Global warming trends in the marine environment currently lead to poleward shifts in the distribution of marine fauna along European coastlines indicating limited thermal tolerance of affected species and potential loss of their southernmost populations. The present study analyses the degree and limits of thermal specialisation in various populations of a key species of the intertidal zone, the lugworm Arenicola marina, which is exposed to highly fluctuating conditions in temperature, salinity, $\mathrm{pH}$ and oxygen levels during the seasonal as well as the tidal cycle. Thermal windows of tolerance and exercise performance were compared in three populations from the Russian White Sea, the German North Sea and the French Atlantic coast. Digging experiments in natural marine sediments quantified performance capacity and its optimum temperature. Temperature dependent ventilation and respiration were analysed in lugworms dwelling in artificial self-perfused burrows. Haemoglobin oxygen affinity was examined for an evaluation of population specific adaptations in the oxygen supply system. The results reflect a shift of both the thermal window and the thermal optimum towards higher temperatures with decreasing latitude. This shift was accompanied by a reduction of performance amplitude, i.e. the absolute number of digging periods, and a widening of the distance between critical temperatures, i.e. the total aerobic window of thermal tolerance.
\end{abstract}

(c) 2009 Elsevier B.V. All rights reserved.

\section{Introduction}

The polychaete Arenicola marina (L.) is a very abundant inhabitant of the intertidal zone. It is accountable for a large fraction of the bioturbation activity in the intertidal, due to its maximum density of more than 40 individuals per $\mathrm{m}^{2}$ (Reise et al., 2001) and its burrows, which are around $20 \mathrm{~cm}$ deep (Krüger, 1971). It is considered as an important ecosystem engineer, which provides oxygen (Volkenborn, 2006), organic material (Krüger, 1971) and habitats to deeper layers of substrate (Reise et al., 2001). The lugworm is distributed over a wide latitudinal cline from the Arctic down to Southern Spain (Ashworth, 1904; Wesenberg-Lund, 1953; Hartmann-Schröder, 1971; Levent, 1998; the Netherlands Ministerie van Verkeer en Waterstaat) and is exposed to widely fluctuating temperature conditions during seasonal as well as tidal cycles. Lugworm populations are specialised on ambient climate conditions and variability as evidenced from patterns of latitudinal adaptation and seasonal acclimatisation of thermal tolerance windows (Sommer and Pörtner, 2002, 2004). In the Arctic, Arenicola marina is restricted to the sublittoral (Hartmann-Schröder, 1971), where it experiences more constant temperature conditions

\footnotetext{
* Corresponding author. Tel.: +49 4714831 1288; fax: +49 47148311149 E-mail address: Christian.Bock@awi.de (C. Bock).
}

than in the intertidal zone. The same holds true for the Mediterranean and the Black Sea, as these semi-enclosed seas do not show large tidal changes. Evidently, lugworms at the northern and southern margins of the distribution range are not exposed to the large temperature fluctuations that their intertidal conspecifics see in areas in between. The northernmost intertidal populations in Europe are consequently those in northern Norway and at the White Sea, while the southernmost intertidal populations are found in southern Spain. While the White Sea population is exposed to temperature fluctuations from 9 to $16{ }^{\circ} \mathrm{C}$ during summer (Zenkevitch, 1963; Berger et al., 2001 and this study), North Sea animals experience 13 to $23{ }^{\circ} \mathrm{C}$ in summer (source: BSH, Bundesamt für Seeschiffahrt und Hydrographie). Atlantic lugworms have to stand even warmer temperatures from 17 to $29{ }^{\circ} \mathrm{C}$ during summer (source: Météo France; Ifremer, 2007).

While thermal responses and limits can be found at various levels of organisation, current evidence indicates temperature sensitivity to be highest at the organismal level through limited capacity of oxygen supply mechanisms to cover oxygen demand (Pörtner, 2001, 2002a). According to the concept of oxygen and capacity limited thermal tolerance oxygen supply becomes limiting at pejus temperatures $\left(T_{p}\right)$ and leads to progressively inadequate oxygen transport to tissues, mirrored in insufficient levels of blood and/or tissue oxygenation in relation to oxygen demand. Beyond low or high critical temperatures 
$\left(\mathrm{T}_{\mathrm{c}}\right)$, metabolism turns anaerobic and only supports time limited survival. Between critical temperatures, limited availability of aerobic energy in excess of baseline oxygen demand likely causes the typical asymmetric temperature dependent performance curve of the whole organism (Angilletta et al., 2002; Pörtner et al., 2004). The residual oxygen supply budget is shared between muscle activity, growth and reproduction, with a performance maximum close to the upper pejus temperature. Towards critical temperatures aerobic performance capacity falls progressively and all functions except those essential for maintenance are reduced.

Quantification of the temperature dependent performance range and optimum is relevant in the light of global warming and climate change. Recently, Pörtner and Knust (2007) could show in marine fish (Zoarces viviparus) from the North Sea that the concept of oxygen and capacity limited thermal tolerance is suitable to explain species responses in the field. Exposure to field temperature extremes beyond the respective performance window led to reduced growth and fitness of the fish, which became manifest in reduced abundance. Muscular activity may also be affected in due course and contribute to a loss in fitness. The reduction in local abundance and finally extinction of a population would eventually cause a shift in the geographical distribution of a species. It has in fact been shown that warming in the marine environment leads to a pole-ward shift in the zoogeography of marine fishes (e.g. Perry et al., 2005).

Respiration measurements over a wide temperature range have been used for determinations of temperature dependent metabolic rate (Pörtner et al., 1998, 2000; Pörtner, 2001). Recent data indicate that the exponential range of temperature dependent standard metabolic rate mirrors the thermal tolerance window between critical temperatures in various animal species (Mark et al., 2002; Melzner et al., 2006b; Wittmann et al., 2008). Ventilation patterns in Arenicola marina and the underlying behaviour have already been studied in response to fluctuating salinities (Shumway and Davenport, 1977). Furthermore, ventilatory and circulatory performance play important roles in defining thermal tolerance, as these processes provide oxygen to tissues (Zielinski and Pörtner, 1996; van Dijk et al., 1999; Frederich and Pörtner, 2000). Earlier work on thermal windows in A. marina identified critical temperatures (Sommer et al., 1997; Sommer and Pörtner, 2002) but was not yet able to evaluate thermal optima and performance curves. Therefore, the present study set out to analyse the windows of temperature dependent performance and their location on the temperature scale in populations of Arenicola marina from the French Atlantic coast, the German North Sea and the Russian White Sea, thereby covering a wide latitudinal cline. Thermal windows as well as performance optima were quantified from patterns of respiration and ventilation in artificial burrows, from digging activity in natural sediments and from haemoglobin oxygen affinity.

\section{Materials and Methods}

\subsection{Animals}

Specimens of the polychaete Arenicola marina (L.) were collected in the intertidal zone at three sampling sites. The northernmost site was located at Kartesh $\left(66.20^{\circ} \mathrm{N}, 33.40^{\circ} \mathrm{E}\right)$ at the White Sea in Russia. These animals were collected in July 2006. The population at DorumNeufeld $\left(53.68^{\circ} \mathrm{N}, 8.57^{\circ} \mathrm{E}\right)$ at the North Sea in Germany was sampled in September 2005 for respiration and ventilation experiments and in August 2006 for burrowing experiments. At the southernmost sampling site in La Hume $\left(44.65^{\circ} \mathrm{N}, 1.17^{\circ} \mathrm{W}\right)$ at the French Atlantic coast, animals were collected in August 2006.

All worms were maintained in basins filled with natural sediment in a natural seawater flow-through aquarium system at the AWI until experimental use. The specimens from the White Sea and from the North Sea were kept at $10{ }^{\circ} \mathrm{C}$, those from the Atlantic at $15{ }^{\circ} \mathrm{C}$. All animals were exposed to a salinity of $32 \%$ and a $12 \mathrm{~h} / 12 \mathrm{~h}$ light/dark cycle in the aquaria and fed with ground and soaked Tetramin ${ }^{\circledR}$ flakes every other week.

\subsection{Field measurements}

Biotic and abiotic field parameters were recorded at all sampling sites in parallel to animal collection. In particular, temperatures in air, tidal puddles and sediment were taken with a thermometer (Testo 925, Testo, Lenzkirch, Germany) using a special temperature-receiving element ( $6 \mathrm{~mm}$ diameter, $500 \mathrm{~mm}$ length, TC Direct, Mönchengladbach, Germany). Salinity was measured in tidal puddles by use of a multiple parameter pocket measurement device (Multi 340i, WTW, Weilheim, Germany). The length of the tail shaft of the worm's burrow was taken as a measure of burrow depth by using a scaled metal stick inserted into the opening of the burrow. For abundance recordings, a $1 \mathrm{~m} \times 1 \mathrm{~m}$ wooden frame was placed onto the intertidal sediment at haphazard counting the number of faecal piles therein. Bodyweight was measured using a scale (EMB 220-I, Kern, Balingen-Frommern, Germany).

\subsection{Digging performance}

Experimental temperatures were chosen at $4{ }^{\circ} \mathrm{C}$ steps, between 3 and $19{ }^{\circ} \mathrm{C}$ for animals from the White Sea and between 7 and $27{ }^{\circ} \mathrm{C}$ for specimens from North Sea and Atlantic. For initial short-term acclimation animals were transferred to a plastic container, covered with a net and placed into a temperature controlled aerated seawater bath. Starting from maintenance conditions temperature was changed at $2{ }^{\circ} \mathrm{Ch}^{-1}$ and kept constant for at least $12 \mathrm{~h}$ at the new experimental temperature. After acclimation for at least 12 hours, animals were transferred into the experimental setup one hour prior to measurements.

The experimental setup comprised an insulated bath of sea water (35 $\mathrm{cm} \times 90 \mathrm{~cm} \times 45 \mathrm{~cm}$, Coleman ${ }^{\circledR}$, Wichita, USA) connected to a thermostat (Integral T 1200, Lauda, Lauda-Königshofen, Germany). Eight plastic vessels (19 cm height, $12.5 \mathrm{~cm}$ diameter, Nalgene ${ }^{\circledR}$, Rochester, USA), 75\% filled (to a level of about $15 \mathrm{~cm}$ ) with autoclaved sediment from the intertidal close to Dorum-Neufeld, were placed on a grid inside the Coleman ${ }^{\circledR}$ box. Prior to experimentation, air stones were removed and the water was decanted to $2 \mathrm{~cm}$ above the sediment surface. After weighing, the animals were positioned on the sediment surface. The duration of each digging period (i.e. the period which started when the worm was placed onto the sediment and ended when it was burrowed to the beginning of its tail region) was recorded using a stopwatch. For an analysis of burrowing capacity during a limited time window this routine was repeated for 90 minutes and the number of digging periods was recorded. Temperature was monitored once every 15 minutes. In total, five specimens of each group were examined at each temperature $(n=5)$.

\subsection{Respiration and ventilation experiment}

Analyses of respiration and ventilation activity were carried out as described previously (Wittmann et al., 2008). Briefly, measurements were performed in the dark using artificial burrows consisting of straight Perspex tubes with a rough inner surface. As in their natural burrows, animals generated a water current to provide themselves with oxygen. Air saturation of incurrent and excurrent water was monitored continuously with oxygen micro-optodes (PreSens, Regensburg, Germany). The volume flow produced by the worms was measured using an electromagnetic flowmeter (inner diameter of probe head: $3 \mathrm{~mm}$, RT500, Hugo Sachs Elektronik, March-Hugstetten, Germany).

Experiments started at a temperature of $10.7{ }^{\circ} \mathrm{C}$ for animals from the White Sea and at $15.0^{\circ} \mathrm{C}$ for animals from both Atlantic and North Sea. Temperature was changed at a rate of $1{ }^{\circ} \mathrm{Ch}^{-1}$ (first lowered) by steps of $3{ }^{\circ} \mathrm{C}$ and kept constant for $6 \mathrm{~h}$. Subpolar lugworms were exposed to a temperature range from $-0.2{ }^{\circ} \mathrm{C}$ to $22.2{ }^{\circ} \mathrm{C}$, temperate 
Table 1

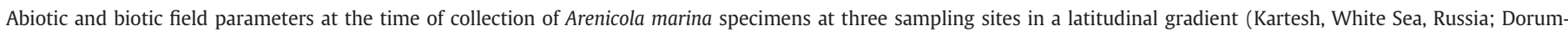
Neufeld, North Sea, Germany; La Hume, Atlantic, France), mean values \pm SD.

\begin{tabular}{|c|c|c|c|c|c|c|c|}
\hline Sampling site and month & Salinity (\%०) & $\mathrm{T}\left({ }^{\circ} \mathrm{C}\right)$ air & $\mathrm{T}\left({ }^{\circ} \mathrm{C}\right)$ tidal puddles & $\mathrm{T}\left({ }^{\circ} \mathrm{C}\right)$ in $20 \mathrm{~cm}$ depth & Length of tail shaft $(\mathrm{cm})$ & Abundance $\left(\mathrm{m}^{-2}\right)$ & Weight $(\mathrm{g})$ \\
\hline White Sea & $25.4 \pm 1.4$ & $16.8 \pm 2.2$ & $17.5 \pm 5.5$ & $13.5 \pm 1.3$ & $10.7 \pm 2.6$ & $28.5 \pm 4.5$ & $5.3 \pm 1.6$ \\
\hline July 2006 & $\mathrm{n}=20$ & $\mathrm{n}=20$ & $\mathrm{n}=20$ & $\mathrm{n}=20$ & $\mathrm{n}=\overline{20}$ & $\mathrm{n}=20$ & $\mathrm{n}=30$ \\
\hline North Sea & $27.4 \pm 0.2$ & $23.6 \pm 0.7$ & $25.8 \pm 1.0$ & $18.9 \pm 1.1$ & $17.3 \pm 2.5$ & $18.0 \pm 3.7$ & $6.3 \pm 1.0$ \\
\hline September 2005 & $\mathrm{n}=10$ & $\mathrm{n}=10$ & $\mathrm{n}=10$ & $\mathrm{n}=10$ & $\mathrm{n}=10$ & $\mathrm{n}=10$ & $\mathrm{n}=30$ \\
\hline North Sea & $28.1 \pm 1.9$ & $23.2 \pm 1.7$ & $25.8 \pm 0.6$ & $22.7 \pm 0.4$ & $14.5 \pm 1.7$ & $27.4 \pm 6.9$ & $6.1 \pm 1.7$ \\
\hline July / August 2006 & $\mathrm{n}=20$ & $\mathrm{n}=20$ & $\mathrm{n}=20$ & $\mathrm{n}=20$ & $\mathrm{n}=20$ & $\mathrm{n}=20$ & $\mathrm{n}=30$ \\
\hline Atlantic & $34.1 \pm 0.6$ & $22.1 \pm 2.4$ & $25.8 \pm 4.1$ & $22.2 \pm 0.8$ & $12.9 \pm 2.9$ & $28.4 \pm 11.2$ & $5.7 \pm 1.8$ \\
\hline August 2006 & $\mathrm{n}=20$ & $\mathrm{n}=20$ & $\mathrm{n}=20$ & $\mathrm{n}=20$ & $\mathrm{n}=20$ & $\mathrm{n}=20$ & $\mathrm{n}=30$ \\
\hline
\end{tabular}

animals experienced a range from $2.8{ }^{\circ} \mathrm{C}$ to $26.0{ }^{\circ} \mathrm{C}$. Mean oxygen partial pressure of incurrent and excurrent water $\left(\mathrm{P}_{\mathrm{IO} 2}\right.$ and $\left.\mathrm{P}_{\mathrm{EO} 2}, \mathrm{kPa}\right)$ and weight specific volume flow $\left(\mathrm{V}_{\mathrm{w}}, \mathrm{ml} \mathrm{h}^{-1} \mathrm{~g}^{-1}\right)$ were calculated for the last $3 \mathrm{~h}$ of each incubation period. From these data oxygen consumption $\left(\mathrm{M}_{\mathrm{O} 2}, \mu \mathrm{mol} \mathrm{O}_{2} \mathrm{~h}^{-1} \mathrm{~g}^{-1}\right)$ and the extraction coefficient (\%) were determined. The analysis also included the mean volume flow during the phases of active ventilation (active volume flow, $\mathrm{ml} \mathrm{min}^{-1}$ ) and the number of contraction waves of the body wall (pumping frequency, $\mathrm{min}^{-1}$ ). The water volume transported per peristaltic wave of the body wall musculature (wave volume, ml, see Wittmann et al., 2008) was calculated from volume flow recordings during active ventilation periods.

\subsection{Haemoglobin functional properties}

On each occasion when animals were collected from the field, 3 to 8 worms were used to collect blood for isolating haemoglobin and for determining its oxygen affinity under standardised conditions. An oxygen diffusion chamber technique (Krogh-Rasmussen and Weber, 1979) was used to investigate the oxygen binding properties of haemoglobin as described previously (Wittmann et al., 2008). Effects of $\mathrm{pH}$ or modulators of the oxygen binding curve such as inorganic ions were eliminated through separation of the haemoglobin from blood plasma by Microcon YM-100 centrifugal devices (Millipore, Bedford, USA) and resuspension in $10 \mathrm{mmol}^{-1}$ HEPES buffer at $\mathrm{pH} 7.5$. A spectrophotometer (U-1100, Hitachi, Japan) was used to record the absorption of $5 \mu \mathrm{l}$ subsamples placed as a thin layer inside a thermostatted flow through chamber. Oxygen partial pressure of the gas flowing through the chamber was changed at $1 \%$ intervals by mixing room air and nitrogen with a gas mixing pump (2M303/a-f, Wösthoff, Bochum, Germany). As the partial pressure of carbon dioxide could not be controlled by this setup, $\mathrm{pH}$ changes in the haemoglobin solution were minimized by diluting $0.5 \mu$ samples 10 fold in $1 \mathrm{~mol} \mathrm{l}^{-1} \mathrm{HEPES}$ buffer at $\mathrm{pH}$ 7.0. All measurements took place at $20^{\circ} \mathrm{C}$ and $\mathrm{pH}$ 7.0. This approach was applied to detect functional differences between haemoglobins from different populations.

\subsection{Statistics}

Statistical analysis was performed using GraphPad Prism version 4.0c for Macintosh (GraphPad Software, San Diego, California, USA). Nonlinear regression curves were fitted to temperature dependent burrowing activities, using the equation $\operatorname{EP}(T)=F_{1}(T)+F_{2}(T)=\left(A_{1} e^{B 1 T}+C_{1}\right)+$ $\left(\mathrm{A}_{2} \mathrm{e}^{\mathrm{B} 2 \mathrm{~T}}+\mathrm{C}_{2}\right)$ according to Pörtner and Knust (2007). For oxygen consumption data the equation $\mathrm{M}_{\mathrm{O} 2}(\mathrm{~T})=\mathrm{Ae}^{\mathrm{BT}}+\mathrm{C}$ and for active volume flow the equation $V_{W}(T)=A e^{B T}+C$ were used as described in Wittmann et al. (2008). Significant deviations of $\mathrm{M}_{\mathrm{O} 2}$ and $\mathrm{V}_{\mathrm{W}}$ values from the hypothetical value extrapolated from the exponential relationship were identified by One-sample Student's t-test. One-way ANOVA was performed to detect significant changes in active volume flow, pumping frequency, wave volume, mean $\mathrm{P}_{\mathrm{EO} 2}$ and extraction coefficient over the temperature range within each population (F-test). Two-way ANOVA combined with a Bonferroni posthoc test was applied to detect significant differences in active volume flow, pumping frequency and wave volume between populations at each temperature. $Q_{10}$ values were calculated for specific temperature ranges using standard procedures as in Sommer and Pörtner (2002). One-way ANOVA and Tukeys posthoc test were used to identify differences in field data and in haemoglobin oxygen affinity $\left(\mathrm{P}_{50}\right)$ between the groups. Statistical significance was identified at the $p \leq 0.05$ level. All data are given as means $\pm S E$ if not stated otherwise.

\section{Results}

\subsection{Field measurements}

Table 1 presents biotic and abiotic field parameters at each sampling site to characterise the natural conditions of the lugworm's habitat at the time of collection during the respective summer. The lowest salinity was found at the White Sea site, the highest at the Atlantic site, whereas North Sea sites displayed intermediate salinity. Similar air temperatures were measured at North Sea and Atlantic sites compared to significantly $(\mathrm{p}<0.001)$ lower values at the subpolar sampling site. Surface water temperatures in both years were similar at North Sea and Atlantic sites, while the White Sea again showed significantly $(p<0.001)$ lower values. Temperatures at $20 \mathrm{~cm}$ depth were also significantly $(\mathrm{p}<0.001)$ lower at the subpolar sampling site and very similar at Atlantic and North Sea sites. It is notable that both the northernmost and southernmost populations sampled (White Sea and Atlantic) displayed significantly shallower burrows (White Sea: $\mathrm{p}<0.001$; Atlantic vs North Sea 2005: $\mathrm{p}<0.001$ ) and a trend for lower body weights than the geographically more central North Sea population. Abundance was similar at all three sampling sites except for the North Sea in 2005, when richness was significantly lower $(\mathrm{p}<0.01$ vs White Sea and Atlantic; $\mathrm{p}<0.05$ vs North Sea 2006).

\subsection{Digging performance}

Fig. 1 shows the temperature dependent number of digging periods per 90 min experimental period. Values are given as means \pm SE. During the 90 minutes time window animals from the White Sea were able to burrow up to $8.00 \pm 0.45$ times at $10.8^{\circ} \mathrm{C}$. Performance showed a more or less symmetrical decrease towards both lower and higher temperatures. The lowest and highest experimental temperatures $\left(3.0^{\circ} \mathrm{C}\right.$ and $\left.18.8^{\circ} \mathrm{C}\right)$ led to $4.00 \pm 0.71$ and $3.60 \pm 0.68$ digging periods $90 \mathrm{~min}^{-1}$, respectively. The regression analysis of performance of the subpolar lugworms displayed a maximum of 7.23 digging periods $90 \mathrm{~min}^{-1}$ at $11.8^{\circ} \mathrm{C}$.

North Sea animals acclimated to the same temperature as White Sea animals $\left(10^{\circ} \mathrm{C}\right)$ showed a maximum burrowing capacity of $8.00 \pm 0.41$ digging periods $90 \mathrm{~min}^{-1}$ at $15.0^{\circ} \mathrm{C}$. Their performance decreased more rapidly towards higher as well as lower incubation temperatures, reaching $4.00 \pm 0.55$ digging periods at $19.0^{\circ} \mathrm{C}$ and less than $490 \mathrm{~min}^{-1}$ at $10.8{ }^{\circ} \mathrm{C}$. With further cooling, performance capacity remained constant while warming led to a loss of digging capacity at $27.0{ }^{\circ} \mathrm{C}$. The performance model displayed a maximum of 5.48 periods $90 \mathrm{~min}^{-1}$ at $14.5^{\circ} \mathrm{C}$. 

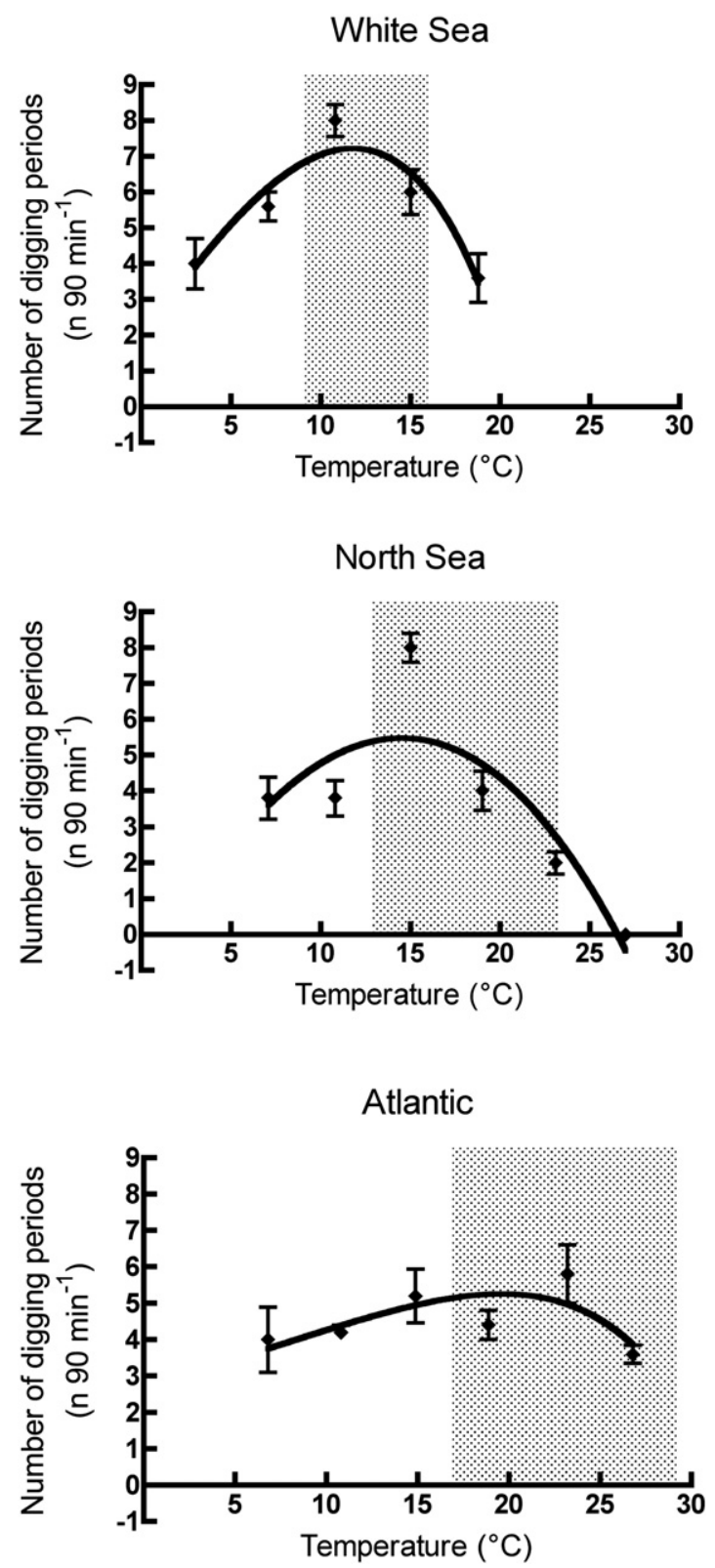

Fig. 1. Temperature dependent burrowing capacity in Arenicola marina. Mean values $\pm \mathrm{SE}$ for animals collected in summer 2006 at White Sea, North Sea and Atlantic. $n=5$ $\left(\mathrm{n}=4\right.$ for North Sea at $15.0^{\circ} \mathrm{C}$ ). White Sea animals were acclimated to $10{ }^{\circ} \mathrm{C}$ and tested between 3.0 and $18.8^{\circ} \mathrm{C}$. North Sea specimens were acclimated to $10^{\circ} \mathrm{C}$, Atlantic animals to $15^{\circ} \mathrm{C}$. North Sea and Atlantic animals were investigated between 7 and $27^{\circ} \mathrm{C}$. Data were fitted to the equation $\operatorname{EP}(T)=F_{1}(T)+F_{2}(T)=\left(A_{1} e^{B 1 T}+C_{1}\right)+\left(A_{2} e^{B 2 T}+C_{2}\right)$ with $\operatorname{EP}(T)=$ temperature dependent muscle exercise performance capacity. The first term, $F_{1}(T)=$ $\mathrm{A}_{1} \mathrm{e}^{\mathrm{B} 1 \mathrm{~T}}+\mathrm{C}_{1}$, represents the temperature dependence of aerobic processes supporting exercise performance. The second term, $F_{2}(T)=A_{2} e^{B 2 T}+C_{2}$, represents the parallel exponential rise in processes limiting aerobic scope and thus exercise performance capacity. For the White Sea data: $A_{1}=54.10, B_{1}=0.03008, C_{1}=-20.11, A_{2}=-11.07$, $B_{2}=0.08079, C_{2}=-21.09, r=0.7582$. For the North Sea data: $A_{1}=1756, B_{1}=0.004424$, $C_{1}=-613.9, A_{2}=-528.6, B_{2}=0.01298, C_{2}=-615.0, r=0.8093$. For the Atlantic data: $\mathrm{A}_{1}=4.083, \mathrm{~B}_{1}=0.06221, \mathrm{C}_{1}=-0.4553, \mathrm{~A}_{2}=-1.081, \mathrm{~B}_{2}=0.1038, \mathrm{C}_{2}=0.1652, \mathrm{r}=0.3723$. Shaded area: naturally experienced habitat temperatures from June to August.

Exercise performance in Atlantic animals differed from the other populations. A clear performance maximum was not discernible; none of the values differed significantly from the others. Burrowing capacity was $5.80 \pm 0.80$ digging periods $90 \mathrm{~min}^{-1}$ at $23.2{ }^{\circ} \mathrm{C}$ compared to the experimental maxima of 8 periods in the other two populations. At the lowest incubation temperature of $6.8^{\circ} \mathrm{C}$, Atlantic worms showed $4.00 \pm 0.89$ digging periods $90 \mathrm{~min}^{-1}$. A steeper decrease in digging activity was visible in the Atlantic population between 23.2 and $26.8^{\circ} \mathrm{C}$ when the lowest value of $3.60 \pm$ 0.24 digging periods $90 \mathrm{~min}^{-1}$ was reached. The regression fit resulted in an asymmetric curve with a maximum value of 5.26 digging periods $90 \mathrm{~min}^{-1}$ at $19.6{ }^{\circ} \mathrm{C}$.

\subsection{Respiration and ventilation experiment}

Oxygen consumption ( $\mathrm{M}_{\mathrm{O} 2}$, $\mu \mathrm{mol} \mathrm{O}_{2} \mathrm{~g}^{-1} \mathrm{~h}^{-1}$ ) increased exponentially in all populations (Fig. 2). In White Sea animals, an exponential curve covered the whole experimental temperature range from -0.2 to $22.2{ }^{\circ} \mathrm{C}\left(\mathrm{Q}_{10}\right.$ value of $\left.2.69 \pm 0.45\right)$, starting with a minimum of $0.44 \pm 0.30 \mu \mathrm{mol} \mathrm{O} \mathrm{g}^{-1} \mathrm{~h}^{-1}$ at $-0.2^{\circ} \mathrm{C}$ and a maximum of $3.13 \pm 0.56 \mu \mathrm{mol} \mathrm{O} \mathrm{O}_{2} \mathrm{~g}^{-1} \mathrm{~h}^{-1}$ at $22.2^{\circ} \mathrm{C}$. Some animals died at the highest temperatures tested (see legend Fig. 2).

North Sea lugworms showed their lowest oxygen consumption rates of $0.12 \pm 0.04 \mu \mathrm{mol} \mathrm{O} \mathrm{O}_{2} \mathrm{~g}^{-1} \mathrm{~h}^{-1}$ at $2.8^{\circ} \mathrm{C}$, below the exponential range found between 5.4 and $23.5^{\circ} \mathrm{C}$. At $26.0^{\circ} \mathrm{C}$ oxygen consumption had increased to $2.37 \pm 0.42 \mu \mathrm{mol} \mathrm{O}_{2} \mathrm{~g}^{-1} \mathrm{~h}^{-1}$, a value also significantly below the exponential regression curve. The exponential increment followed a $\mathrm{Q}_{10}$ value of $1.81 \pm 0.43$. All animals survived the experimental treatment. Upon cooling, one individual abandoned ventilation activity already at $5.4{ }^{\circ} \mathrm{C}$, such that cooling was discontinued for that specimen $\left(\mathrm{n}=4\right.$ at $\left.2.8^{\circ} \mathrm{C}\right)$. In the Atlantic population $(\mathrm{n}=5)$, oxygen consumption increased exponentially from $0.90 \pm$ 0.22 at $5.3^{\circ} \mathrm{C}$ up to $3.47 \pm 0.53 \mu \mathrm{mol} \mathrm{O}_{2} \mathrm{~g}^{-1} \mathrm{~h}^{-1}$ at $25.7^{\circ} \mathrm{C}$ following a $\mathrm{Q}_{10}$ of $2.14 \pm 0.35$. At $2.9^{\circ} \mathrm{C}$ oxygen consumption remained significantly below the exponential curve.

White Sea lugworms showed a steady increase in active volume flow (Fig. 3) from $-0.2{ }^{\circ} \mathrm{C}$ to $19.7^{\circ} \mathrm{C}$ and a subsequent slight decline at $22.2^{\circ} \mathrm{C}$. Active volume flow was significantly higher than in North Sea animals at 17.2 and $19.7^{\circ} \mathrm{C}$ and significantly higher than in Atlantic worms at $19.7{ }^{\circ} \mathrm{C}$. Pumping frequency (the number of body wall contractions $\mathrm{min}^{-1}$ ) developed in a similar way, rising steadily from $-0.2^{\circ} \mathrm{C}$ up to $19.7^{\circ} \mathrm{C}$ followed by a slight decrement at $22.2^{\circ} \mathrm{C}$. Values were significantly higher compared to the other populations at 17.2 and $19.7^{\circ} \mathrm{C}$. At $22.2^{\circ} \mathrm{C}$ pumping rate was still significantly higher than in the Atlantic population. Wave volume (the water volume in $\mathrm{ml}$ transported per contraction wave) displayed a similar pattern, rising from $-0.2{ }^{\circ} \mathrm{C}$ to a maximum at $19.7^{\circ} \mathrm{C}$.

Active volume flow in North Sea lugworms rose from 2.8 to $23.5^{\circ} \mathrm{C}$ with a slight decrease towards the highest incubation temperature of $26.0^{\circ} \mathrm{C}$. Pumping frequency rose steadily over the whole experimental temperature range. Wave volume in North Sea animals was lowest at $2.8^{\circ} \mathrm{C}$ and highest at $23.5^{\circ} \mathrm{C}$. As in White Sea and Atlantic animals, active volume flow and pumping frequency increased significantly upon warming. Wave volume, in contrast, remained more or less unchanged in North Sea specimens, while it showed a significant rise in the other populations.

The Atlantic population showed a significant rise in active volume flow from $2.9^{\circ} \mathrm{C}$ to $25.7^{\circ} \mathrm{C}$. At low temperatures values were slightly higher than in the other populations, but at $20.1{ }^{\circ} \mathrm{C}$, the value was significantly lower than in White Sea worms, resulting in a slightly lower $\mathrm{Q}_{10}$ value. Pumping frequency in the Atlantic population rose only slightly between $2.9{ }^{\circ} \mathrm{C}$ and $23.2{ }^{\circ} \mathrm{C}$ but showed a steeper increase at $25.7{ }^{\circ} \mathrm{C}$. In general, the pumping frequency in Atlantic animals was significantly lower than in White Sea specimens at temperatures $\geq 17.5^{\circ} \mathrm{C}$, but comparable to worms from the North Sea. The Atlantic population produced significantly higher wave volumes than the North Sea group at 17.5 and $23.2{ }^{\circ} \mathrm{C}$. Wave volume rose significantly from $2.9{ }^{\circ} \mathrm{C}$ to $23.2^{\circ} \mathrm{C}$, followed by a slight decline at $25.7^{\circ} \mathrm{C}$.

Fig. 4 shows the mean oxygen partial pressure in the outflowing water (mean $\mathrm{P}_{\mathrm{EO} 2}, \mathrm{kPa}$ ) and the oxygen extraction coefficient (\%). In all three populations, changes in $\mathrm{P}_{\mathrm{EO} 2}$ and extraction coefficient with 

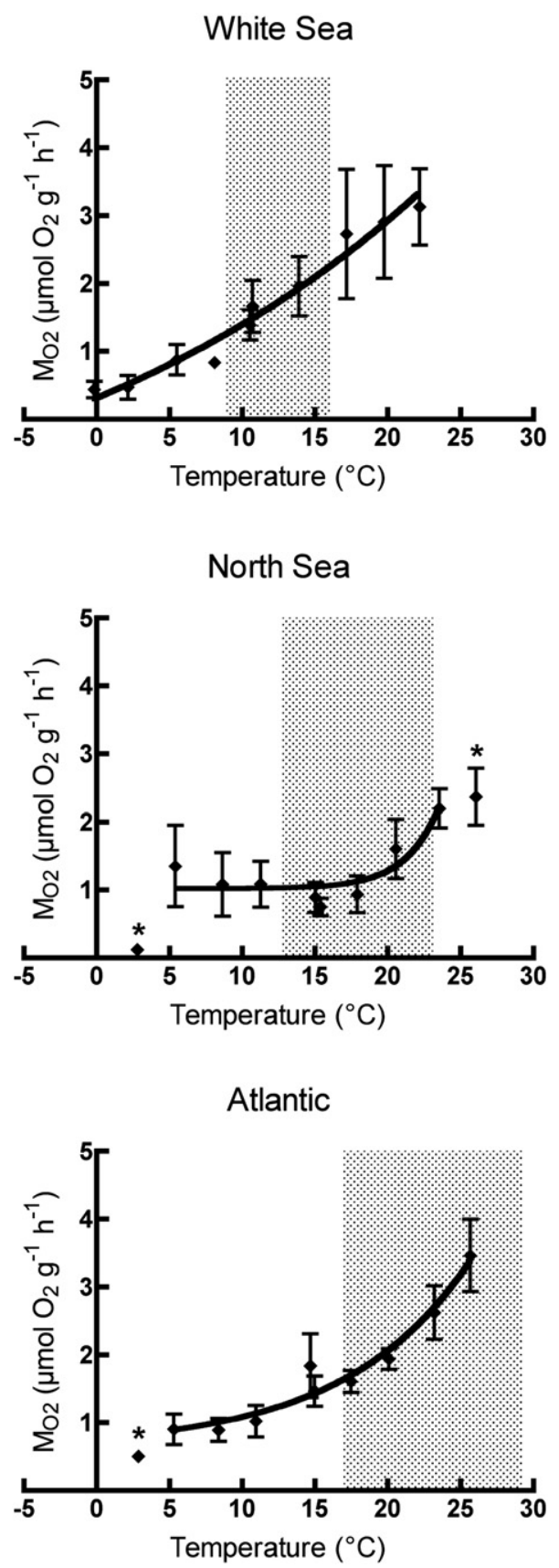

Fig. 2. Temperature $\left({ }^{\circ} \mathrm{C}\right)$ dependent oxygen consumption $\left(\mu \mathrm{mol}_{2} \mathrm{~g}^{-1} \mathrm{~h}^{-1}\right.$, mean values $\left.\pm \mathrm{SE}\right)$ in Arenicola marina dwelling in an artificial burrow. Animals were collected in summer 2005 at the North Sea and in summer 2006 at the Atlantic and the White Sea. For North Sea animals: $\mathrm{n}=5$ except for $2.8^{\circ} \mathrm{C}$ with $\mathrm{n}=4$. For Atlantic lugworms: $\mathrm{n}=5$. For White Sea specimens: $\mathrm{n}=6$ at $-0.2,2.1,5.5,8.1$ and $10.7^{\circ} \mathrm{C}, \mathrm{n}=5$ at 10.5 and $13.9^{\circ} \mathrm{C}, \mathrm{n}=4$ at 17.2 and $19.7^{\circ} \mathrm{C}$ and $\mathrm{n}=3$ at $22.2^{\circ} \mathrm{C}$. White Sea and North Sea worms were acclimated to $10^{\circ} \mathrm{C}$. Atlantic animals to $15{ }^{\circ} \mathrm{C}$. The subpolar specimens were investigated from -0.2 to $22.2^{\circ} \mathrm{C}$, both temperate populations were exposed from 2.8 to $26.0{ }^{\circ} \mathrm{C}$. Data were fitted to $\mathrm{M}_{\mathrm{O} 2}(\mathrm{~T})=\mathrm{Ae}^{\mathrm{BT}}+\mathrm{C}$ (Wittmann et al., 2008). For the White Sea data: $A=2.576, B=0.03507, C=-2.258$, $r=0.7310$. For the North Sea data: $A=5.3415 \times 10^{-5}, B=0.4262, C=1.021, r=0.4529$. For the Atlantic data: $\mathrm{A}=0.1405, \mathrm{~B}=0.1159, \mathrm{C}=0.6392, \mathrm{r}=0.7703$. Asterisks $(*)$ designate data points, which are significantly different from the exponential regression curve $(\mathrm{p}=0.0002$ for North Sea at $2.8^{\circ} \mathrm{C} ; \mathrm{p}=0.0064$ for North Sea at $26.0^{\circ} \mathrm{C} ; \mathrm{p}=0.0206$ for Atlantic at $2.9{ }^{\circ} \mathrm{C}$ ). Shaded area: naturally experienced habitat temperatures in summer.

temperature were not significant. In White Sea animals, a slight decrease in oxygen extraction efficiency occurred upon warming while mean $\mathrm{P}_{\mathrm{EO} 2}$ remained unchanged. In North Sea animals warming caused a slight decrease in $\mathrm{P}_{\mathrm{EO} 2}$ associated with a small increase in extraction efficiency. In Atlantic animals $\mathrm{P}_{\mathrm{EO} 2}$ decreased and the extraction coefficient increased upon warming.

\subsection{Haemoglobin oxygen binding properties}

Assay conditions were the same for all haemoglobin samples and no differences in $\mathrm{P}_{50}$ could be detected between the three populations from White Sea, North Sea and Atlantic (data not shown). When corrected for the respective field temperature and expected differences in blood $\mathrm{pH}$ at the time of animal collection (Fig. 5), White Sea haemoglobin showed a $\mathrm{P}_{50}$ of $0.20 \pm 0.05 \mathrm{kPa}\left(13.5^{\circ} \mathrm{C}\right)$, which was significantly lower than the $\mathrm{P}_{50}$ of $0.33 \pm 0.10 \mathrm{kPa}\left(22.4^{\circ} \mathrm{C}\right)$ in Atlantic haemoglobin and slightly lower than the $\mathrm{P}_{50}$ of around $0.3 \mathrm{kPa}$ (around $20^{\circ} \mathrm{C}$ ) in North Sea haemoglobin.

\section{Discussion}

Temperature dependent muscular exercise, and thus digging performance, is expected to display an asymmetric bell-shaped curve as predicted by the temperature dependent performance curve according to the concept of oxygen limited thermal tolerance (Pörtner et al., 2004; Pörtner and Knust, 2007; see introduction). The performance optimum is expected close to the upper pejus temperature. The lopsided shape results from the temperature dependent increase in oxygen delivery and functional capacity, which is counterbalanced by rising rates of oxygen demand for maintenance limiting aerobic scope (Pörtner and Knust, 2007).

Burrowing rates have already been used as a measure for temperature dependent performance in clams (Mercenaria mercenaria L. and Spisula solidissima Dillwyn) and resulted in negatively skewed (right-handed) distributions (Savage, 1976). The two clam species exhibited different thermal windows according to their geographical distribution. In the present study, the same pattern was observed in Arenicola marina, when comparing the three populations in a latitudinal cline. During summer, thermal optima rose with decreasing latitudes.

Subpolar lugworms acclimated at $10{ }^{\circ} \mathrm{C}$ showed the highest digging activity at $10.8{ }^{\circ} \mathrm{C}$ (model prediction: $11.8^{\circ} \mathrm{C}$ ). At the time of collection the temperature at $20 \mathrm{~cm}$ depth, in the burrow galleries, was $13.5^{\circ} \mathrm{C}$, close to the average monthly sea surface temperature of $13.2^{\circ} \mathrm{C}$ (Table 1 , compared to $9.1{ }^{\circ} \mathrm{C}$ during the month before, Berger et al., 2001). For comparison, North Sea animals acclimated at $10{ }^{\circ} \mathrm{C}$ showed maximum exercise capacity at a higher temperature of $15.0^{\circ} \mathrm{C}$ (model prediction: $14.5^{\circ} \mathrm{C}$ ). Sampling temperature at $20 \mathrm{~cm}$ depth was $22.7^{\circ} \mathrm{C}$, while sea surface temperature ranged around $20^{\circ} \mathrm{C}$ during the respective month (compared to $15^{\circ} \mathrm{C}$ during the month before, source: BSH, Bundesamt für Seeschiffahrt und Hydrographie). Finally, the Atlantic population, acclimated at $15{ }^{\circ} \mathrm{C}$, displayed a considerably higher thermal optimum than the other two populations, $23.2{ }^{\circ} \mathrm{C}$ (model prediction: $19.6{ }^{\circ} \mathrm{C}$ ). Surprisingly, habitat temperature at $20 \mathrm{~cm}$ depth was slightly lower than at the North Sea site $\left(22.2^{\circ} \mathrm{C}\right)$ with sea surface temperature at $22^{\circ} \mathrm{C}$, only slightly higher than in the North Sea (compared to $25^{\circ} \mathrm{C}$ the month before, Ifremer, 2007). Interestingly, in all three cases the optimum temperature was closer to habitat temperatures of the preceding month indicating some delay in acclimatisation. Also, performance optima were not closely dependent on acclimation temperatures, but may reflect permanent functional differences between populations.

Performance limitation was reached in the North Sea population at $27{ }^{\circ} \mathrm{C}$, indicating the upper critical temperature. Previous studies had identified an upper critical temperature of North Sea lugworms between 20 and $25^{\circ} \mathrm{C}$ during summer (Sommer et al., 1997). In the present study North Sea animals still performed at around $23{ }^{\circ} \mathrm{C}$ indicating an upper critical temperature between 23 and $27{ }^{\circ} \mathrm{C}$. It should be noted that muscular performance in lugworms includes an anaerobic component, which might be thermally less sensitive than the aerobic component. Nonetheless, this observation indicates that some correlation exists 
White Sea
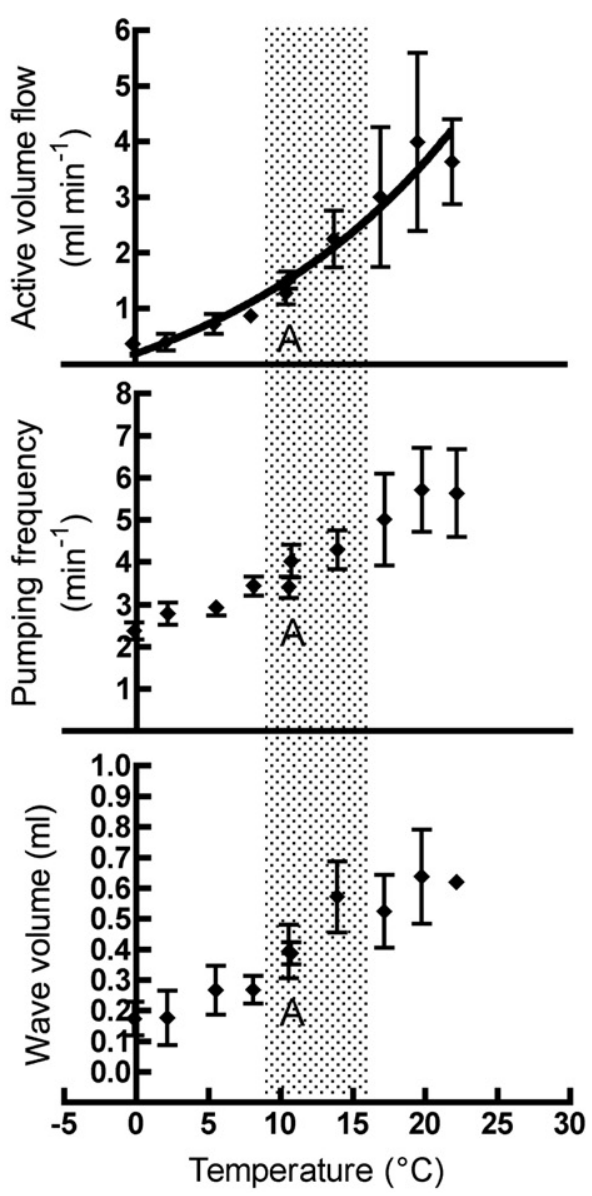

North Sea

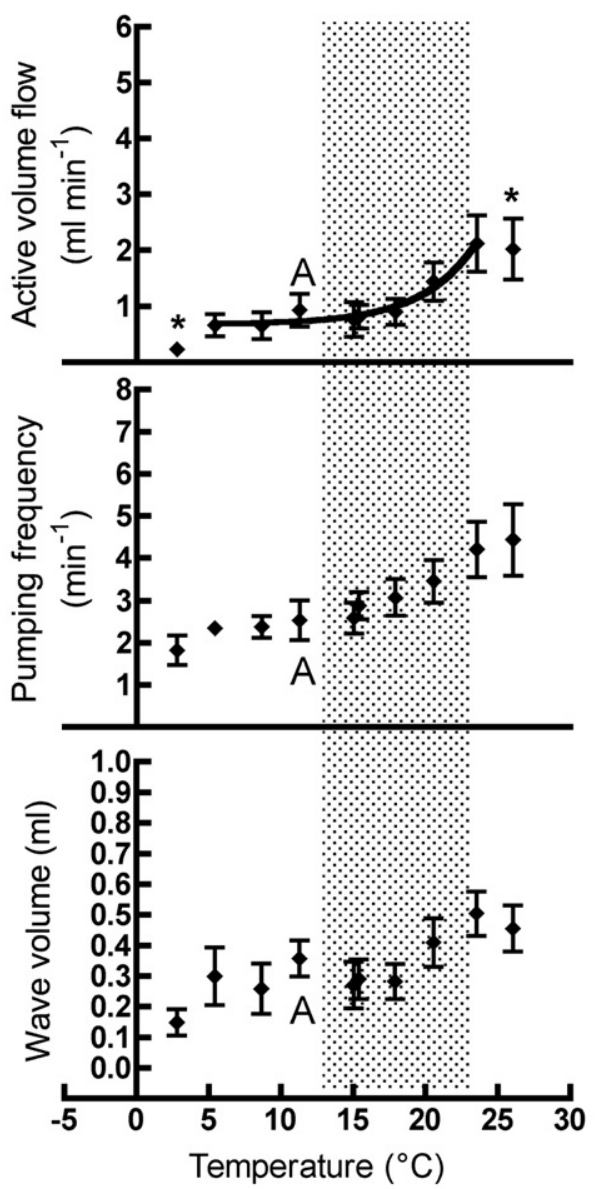

Atlantic

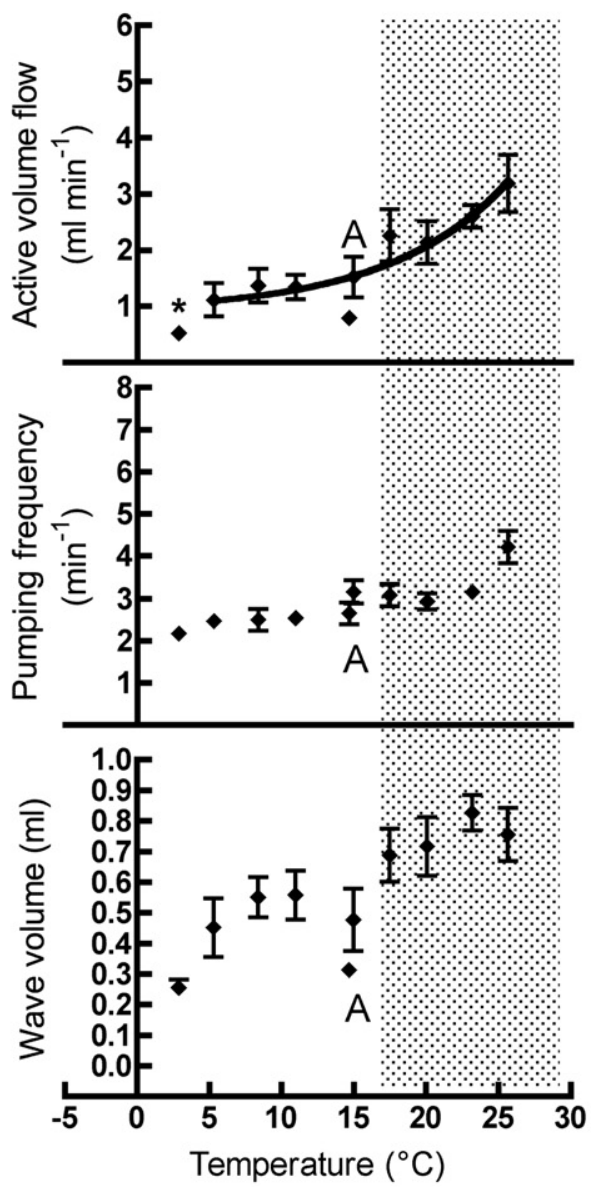

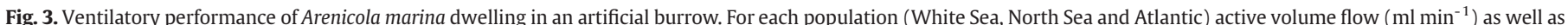

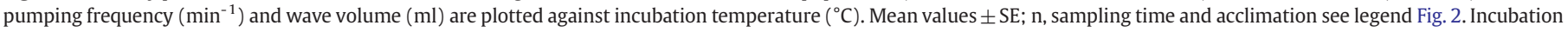

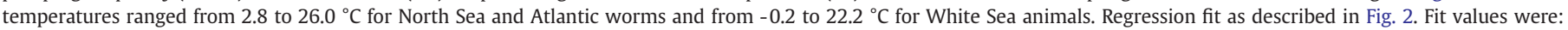

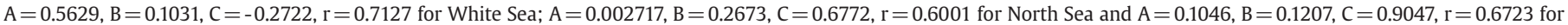

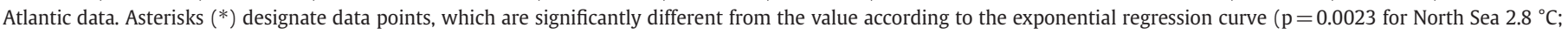
$\mathrm{p}=0.0487$ for North Sea $26.0^{\circ} \mathrm{C} ; \mathrm{p}=0.0005$ for Atlantic $2.9^{\circ} \mathrm{C}$ ). A: acclimation temperature. Shaded area: naturally experienced habitat temperatures in summer.

between upper $\mathrm{T}_{\mathrm{c}}$ according to exercise failure and the $\mathrm{T}_{\mathrm{c}}$ caused by the onset of oxygen deficiency in the animal's burrow.

Deere and Chown (2006) discussed several hypotheses for the influence of acclimation temperature on locomotor performance curves. The beneficial acclimation hypothesis says that "acclimation to a particular environment gives an organism a performance advantage in that environment over another organism that has not had the opportunity to acclimate to that particular environment" (Leroi et al., 1994). The present comparison of distinct (and genetically different) populations (Hummel et al., 1997a) indicates that evolutionary adaptation to a particular environment has the same effect as acclimation. Adaptation is reflected in the shift of performance optima towards higher environmental temperatures at lower latitudes.

Cold-adapted subpolar lugworms displayed the highest performance amplitudes despite a somewhat lower optimal temperature, while warm-adapted Atlantic animals showed the lowest performance maxima. At first sight, this observation would support a "colder is better" hypothesis. However, the width of the performance curves showed a trend to increase from "cold"-adapted towards "warm"adapted animals. Our comparison of burrowing performance in Arenicola marina from various latitudes seems to indicate a trade-off between the width and amplitude of performance curves (cf. Huey and Hertz, 1984; Angilletta et al., 2002; Pörtner, 2006). Also, our findings match the hypothesis that metabolic cold adaptation in eurytherms reflects a preconditioning for enhanced exercise levels (Pörtner, 2002b).
As shown in a recent study (Wittmann et al., 2008), oxygen consumption in lugworms actively ventilating their (artificial) burrows is a suitable measure to characterise the thermal window of aerobic metabolism (in contrast to an experimental setup where the worm dwells in open water or in a burrow perfused by a pump). Thermal exposures in water pumped through a burrow resulted in wider thermal tolerance windows (Sommer and Pörtner, 2002). Under these conditions, animals save energy for ventilation and are passively provided with excess oxygen even at temperatures beyond their own ventilatory limits. The alleviation of ventilatory constraints supports a widening of the thermal tolerance window according to oxygen consumption upon warming (Sommer and Pörtner, 2002).

Under more natural conditions as applied in the present study, oxygen consumption showed the typical exponential increase between critical temperatures (Melzner et al., 2006a; Wittmann et al., 2008). Values outside this window fell below those expected from the exponential curve. This conclusion is confirmed by the similarity of critical temperatures between this study and previous experiments where the $T_{c}$ 's were determined from the onset of mitochondrial anaerobic metabolism in sediment dwelling North Sea animals collected in summer and acclimated to $1{ }^{\circ} \mathrm{C}$ (Sommer et al., 1997). The lower critical temperature was located between 2 and $5{ }^{\circ} \mathrm{C}$, a finding corresponding well to our present data, where metabolic rate at $5.4{ }^{\circ} \mathrm{C}$ was included in the exponential oxygen consumption range while the one at $2.8{ }^{\circ} \mathrm{C}$ deviated significantly from the regression curve. 

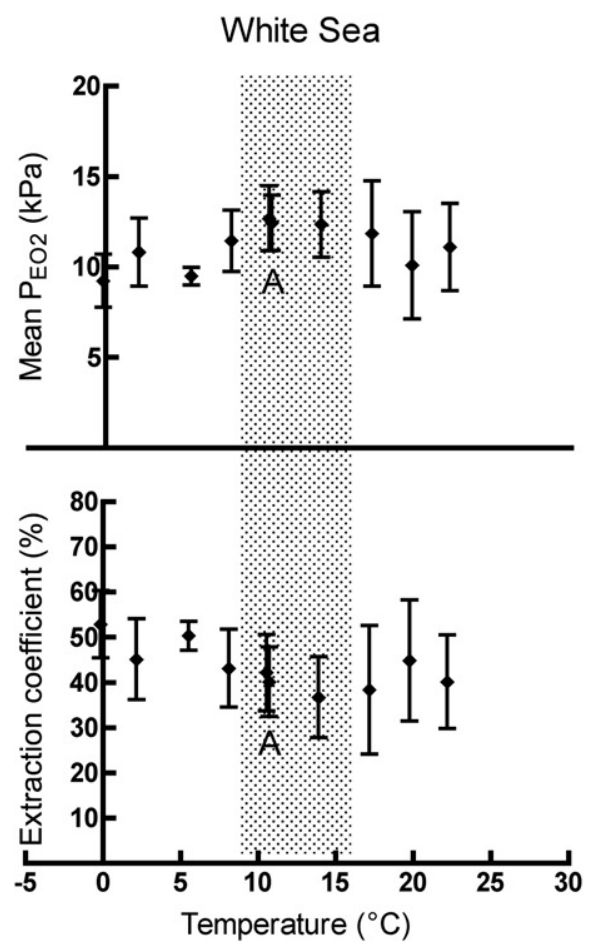

North Sea
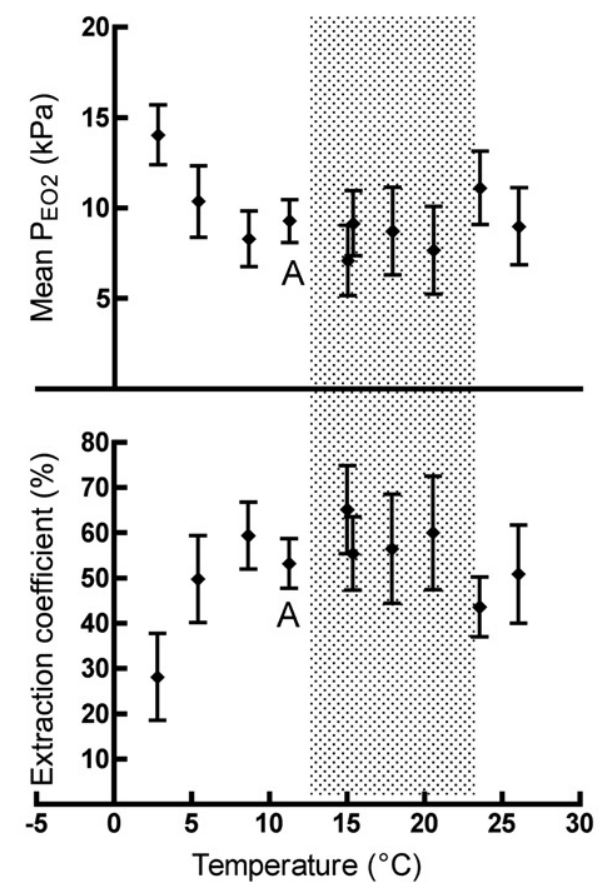

Atlantic
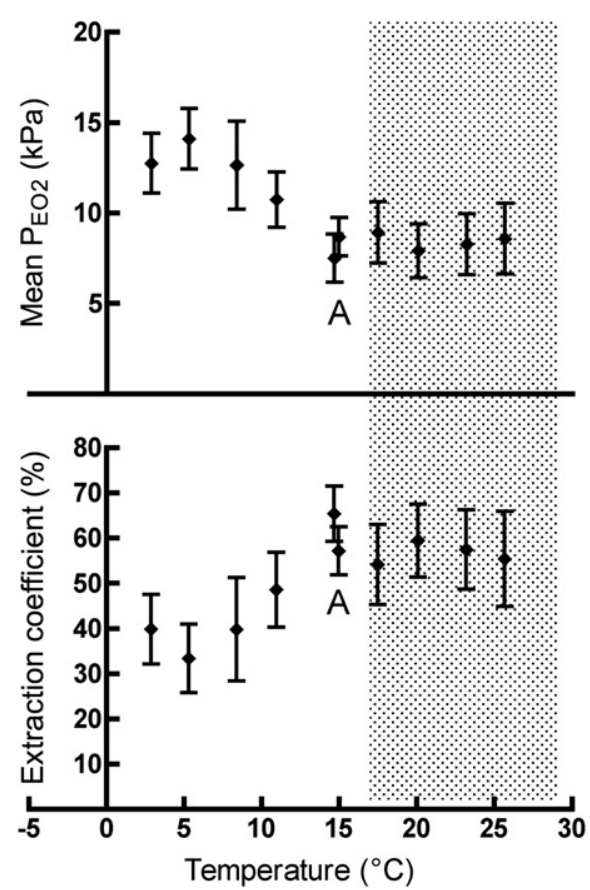

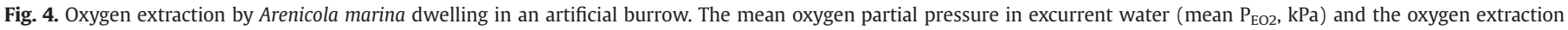
coefficient (\%) versus incubation temperature are shown for the three populations (White Sea, North Sea, Atlantic), mean values \pm SE, for further information see Fig. 2.

Extrapolating the burrowing performance curve towards lower temperatures leads to a somewhat lower critical temperature at $1.6^{\circ} \mathrm{C}$. The upper critical temperature found by Sommer et al. (1997) was located between 20 and $25{ }^{\circ} \mathrm{C}$. The oxygen consumption data in the present study showed a deviation from the exponential curve at $26^{\circ} \mathrm{C}$ indicating a similar $\mathrm{T}_{\mathrm{C}}$ between 23.5 and $26.0^{\circ} \mathrm{C}$. This fits well with the upper $\mathrm{T}_{\mathrm{C}}$ of $26.5{ }^{\circ} \mathrm{C}$ predicted from the performance model. All of these results clearly show the suitability of our approach for determining thermal performance curves in Arenicola marina. Some difference in thermal sensitivity may arise though, between thermal windows according to exercise performance and those found in sediment dwelling specimens from different experimental procedures. Compared to animals dwelling

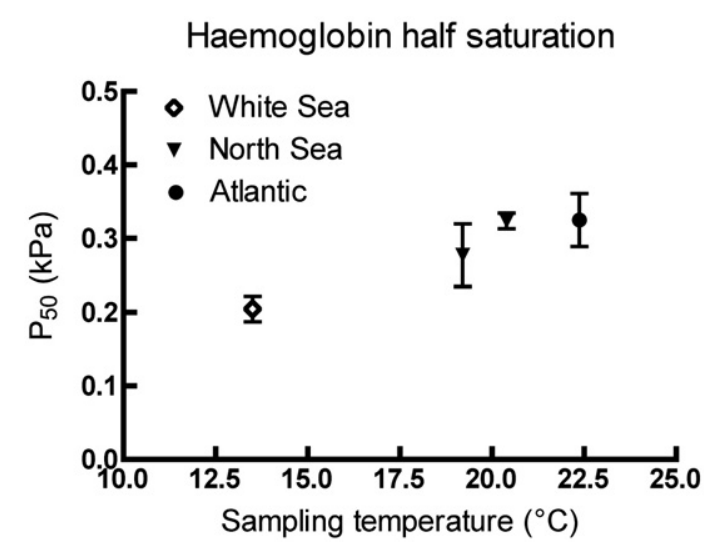

Fig. 5. $\mathrm{P}_{50}=$ oxygen partial pressure when haemoglobin is half saturated $(\mathrm{kPa})$ at animal sampling conditions, measured in isolated haemoglobin from Arenicola marina, mean values \pm SE plotted against sampling temperature $\left({ }^{\circ} \mathrm{C}\right)$. All animals were collected in summer 2006. North Sea lugworms were sampled at Carolinensiel, Germany; White Sea and Atlantic locations were identical with those described above. Measurements took place at $\mathrm{pH} 7.0$ and $20{ }^{\circ} \mathrm{C}$ and were corrected for temperature and blood pH depending on the respective animal sampling sites. $n=3$ for North Sea animals, $n=7$ for Atlantic animals and $n=8$ for White Sea animals. in sediment oxygen availability is in excess for animals repeatedly burrowing at the sediment surface. Furthermore, burrowing animals display elevated rates of energy turnover and rely on anaerobic glycolysis and phosphagen depletion.

The low critical temperature of subpolar lugworms has not previously been identified, but was assumed at around $-1.7^{\circ} \mathrm{C}$, the lowest incubation temperature where tissues were investigated for anaerobic end products (Sommer et al., 1997). The present data indicate no deviation from the exponential phase of oxygen consumption in the low temperature range, indicating a critical $\mathrm{T}$ below $-0.2{ }^{\circ} \mathrm{C}$. Extrapolating from the performance curve leads to failure at $-2.4^{\circ} \mathrm{C}$, close to the $\mathrm{T}_{\mathrm{C}}$ assumed by Sommer et al. (1997). This is clear evidence that the low critical temperature is considerably lower in White Sea than in North Sea animals acclimatised to summer conditions. At the upper critical temperature volatile fatty acid accumulation in the body wall tissue of White Sea animals was initiated between 17 and $21{ }^{\circ} \mathrm{C}$ (Sommer et al., 1997). In our study no deviation from the exponential increase of oxygen demand could be identified according to specimens surviving up to $22.2^{\circ} \mathrm{C}$. However, one out of six worms already died at $13.9^{\circ} \mathrm{C}$, two more out of six at 17.2 and at $19.7^{\circ} \mathrm{C}$. Accordingly, the high mortality rate at temperatures above $14{ }^{\circ} \mathrm{C}$ indicates onset of a clear limitation for some specimens. The remaining oxygen consumption data are thus rates representative of surviving, more tolerant specimens. These observations also suggest existence of large inter-individual variability and appear, overall, well in line with earlier $\mathrm{T}_{\mathrm{c}}$ determinations. In the patterns of active volume flow, pumping frequency and wave volume (Fig. 3) a slight deviation from the steady rise could be observed at a temperature of around $22.2{ }^{\circ} \mathrm{C}$, albeit not significant. From these data, the upper critical temperature would be expected between 19.7 and $22.2^{\circ} \mathrm{C}$. Our performance model in fact predicted an upper $\mathrm{T}_{\mathrm{c}}$ at $21.1^{\circ} \mathrm{C}$.

No literature data exist concerning thermal tolerance of the Atlantic population. Oxygen consumption measurements revealed a low critical threshold similar to the one seen in specimens from the North Sea. Again $\mathrm{M}_{\mathrm{O} 2}$ at the lowest temperature $\left(2.9{ }^{\circ} \mathrm{C}\right)$ deviated significantly from the exponential range. Furthermore, the exponential 
model indicates a higher critical temperature in the warmth than in the North Sea population. However, at the highest incubation temperatures deviation from the exponential model as in the case of the North Sea population could not be found. The rising inter-individual variability at high temperatures might indicate that the animals approached the upper critical temperature. This conclusion is also supported by the slight decrease in wave volume, which was associated with a concomitant steep rise in pumping frequency and a relatively large increase in active volume flow. This increment, especially in pumping frequency, was only observed between 23.2 and $25.7^{\circ} \mathrm{C}$. For reasons discussed above, the performance model resulted in a higher value of the upper critical threshold at $31.7^{\circ} \mathrm{C}$. Further investigations with an extended temperature range are clearly needed to identify the true value of the upper $\mathrm{T}_{\mathrm{c}}$.

Earlier oxygen consumption measurements in North Sea and White Sea lugworms (Sommer and Pörtner, 2002) yielded similar oxygen consumption rates and $\mathrm{Q}_{10}$ values as the present study $(1.67 \pm 0.29$ vs present $Q_{10}$ values of $1.81 \pm 0.43$ in North Sea and $2.84 \pm 0.93$ vs present $2.69 \pm 0.45$ for White Sea animals). Atlantic worms displayed an intermediate $\mathrm{Q}_{10}$ of $2.14 \pm 0.35$. Accordingly, the present study revealed similar $\mathrm{Q}_{10}$ values but narrower thermal windows as discussed above.

Interestingly, both subpolar and Atlantic lugworms showed slightly higher $\mathrm{Q}_{10}$ values than North Sea animals. It may be relevant that the Atlantic as well as the White Sea population both live closer to the border of the distribution range of intertidal populations. Both populations exhibited a trend to display lower body weights and shallower burrow depths. Therefore, growth and performance were possibly affected by less favourable conditions at the margins of the distribution area, as also predicted by the performance capacity model (Schreck, 1981; Hummel et al., 1997b; Hummel, 2003). In this model performance is reflected by features like weight, growth, fitness, stress resistance and reproduction. High or low temperature extremes will reduce performance, since energy is needed to withstand the stressor. At the limits of distribution, performance capacity is thought to be reduced further due to elimination of some ecotypes (Hummel, 2003). The similarities of this concept to the implications of the concept of oxygen and capacity limited thermal tolerance are striking. The latter would provide a mechanistic framework for explanation of temperature dependent performance.

As oxygen demand rises with increasing temperature (Fig. 2), water volume flow for oxygen supply has to increase. This can either take place by rising pumping frequencies or by enhancing the water volume transported per contraction wave. The absolute values for active volume flow (Fig. 3) in White Sea lugworms were higher than in North Sea and Atlantic animals at temperatures $\geq 10.5{ }^{\circ} \mathrm{C}$ (acclimation temperature). This was mainly achieved by enhanced pumping frequency and mirrors the higher energy demand of cold adapted subpolar worms as outlined by Sommer and Pörtner (2002; Pörtner, 2006). Enhanced ventilatory performance is also mirrored by observations of maintained mean oxygen partial pressure in excurrent water of White Sea specimens (Mean $\mathrm{P}_{\mathrm{EO} 2}$, Fig. 4). Interestingly, both North Sea and Atlantic worms showed a decrease in $\mathrm{P}_{\mathrm{EO} 2}$ with temperature. In contrast to the subpolar population, the two temperate populations increased oxygen extraction at higher temperatures, at the expense of reduced aerobic scope due to lower $\mathrm{P}_{\mathrm{O} 2}$. Patterns of cold eurythermal temperature adaptation as seen in White Sea specimens would support temperature compensated functional capacity in the cold and in the warmth (cf. Pörtner, 2006).

As to the contribution of blood pigment function to thermal tolerance our measurements confirmed that the $\mathrm{P}_{50}$ was similar in all three populations when measured at the same temperature, excluding a functional difference of the haemoglobin molecule between populations. Blood borne modulators have not been investigated but might affect oxygen affinity. While these $P_{50}$ values are likely artefactual with respect to true values displayed in vivo, the data indicate that White Sea animals might use these haemoglobins at cooler habitat temperature $\left(13.5^{\circ} \mathrm{C}\right)$ and thus lower $\mathrm{P}_{50}$ values than the other two populations at their respective summer temperature (around $20^{\circ} \mathrm{C}$ ), despite similar oxygen consumption values.

Active volume flow reached similar values at around $20^{\circ} \mathrm{C}$ in North Sea and Atlantic worms and at around $13.5{ }^{\circ} \mathrm{C}$ in White Sea animals, reflecting cold compensated functioning in the latter. As already outlined by Newell (1969), comparable individuals of a species with a wide geographical range show similar levels of activity at their respective habitat temperature at the northern and southern limits of their distribution. Pumping frequency and wave volume, however, were less similar. Atlantic lugworms seem to employ a different strategy during warming than the other populations. They maintained a very constant pumping frequency with increased wave volumes, while in White and North Sea animals both, a rise in pumping frequency and wave volume, contributed to an increase in active volume flow.

Comparing thermal optima and the temperature envelope defined by critical temperatures with the temperature range experienced in summer in the respective habitat, a clear relationship can be recognised. The natural temperature range becomes broader and shifts towards higher values with decreasing latitude. This is mirrored in the range of passive tolerance (between $\mathrm{T}_{\mathrm{c}}$ 's) to extreme temperatures. Atlantic animals displayed the broadest widths and covered the highest temperatures, whereas White Sea specimens showed the narrowest windows covering the lowest temperatures. In all three populations, habitat temperatures ranged in the right half of the thermal tolerance window according to respiration and the performance curve. The performance optimum was found near the left border of the natural range, to the right of the center of the thermal tolerance window bordered by critical temperatures.

In all cases, the respective pejus temperature, defined as the earliest limit beyond which organismal performance will be hampered, falls within current summer temperatures indicating that animals will regularly experience thermal limitations during warm summers (Fig. 1). They are most likely pre-adapted to sustain summer extremes passively in their protected environments. As expected for intertidal species (Pörtner, 2002a) they exceed the pejus range of performance during limited periods of heat exposure in the field. Furthermore, they may shift their main activity periods (growth, reproduction) to spring or fall, outside of present summer temperature maxima.

Currently, maximum water temperatures reach $16{ }^{\circ} \mathrm{C}$ at the White Sea (Zenkevitch, 1963; Berger et al., 2001 and this study), while the upper critical temperature is found around $21^{\circ} \mathrm{C}$ (difference: $5{ }^{\circ} \mathrm{C}$ ). At the North Sea, habitat temperatures rise up to $23{ }^{\circ} \mathrm{C}$ (Bundesamt für Seeschiffahrt und Hydrographie), while the upper critical temperature is found around $26{ }^{\circ} \mathrm{C}$ (difference: $3{ }^{\circ} \mathrm{C}$ ). For the Atlantic population this difference is even smaller $\left(2{ }^{\circ} \mathrm{C}\right)$. They experience a maximum habitat temperature of $29{ }^{\circ} \mathrm{C}$ (Météo France; Ifremer, 2007) close to the upper critical temperature of around $31{ }^{\circ} \mathrm{C}$.

In case of climate change, associated increases in temperature minima and maxima would not only force all three Arenicola populations more often into their upper pejus range but would even reach or exceed critical temperatures, especially at low latitudes. In the German Bight (North Sea) an increase in sea surface temperature has occurred by $1.13^{\circ} \mathrm{C}$ during the past 40 years (Wiltshire and Manly, 2004). In Arcachon Bay, a significant rise by $0.97^{\circ} \mathrm{C}$ was found over a period of 18 years (Sauriau, 1991). Models predict further increments for the North Sea by up to $3.9^{\circ} \mathrm{C}$ during the next 100 years (Sheppard, 2004), beyond critical limits of North Sea lugworms. Assuming similar increments for the other sampling sites, the Atlantic population would be the first that experiences temperature maxima beyond critical limits.

Increasing maximum and minimum summer temperatures would result in a habitat temperature range clearly above observed performance optima. A performance optimum at around $11^{\circ} \mathrm{C}$ was observed in 
White Sea specimens while lowest summer temperatures are around $9{ }^{\circ} \mathrm{C}$ (difference: $2{ }^{\circ} \mathrm{C}$ ). North Sea animals showed a performance optimum at about $15{ }^{\circ} \mathrm{C}$ with lowest summer values around $13{ }^{\circ} \mathrm{C}$ (difference: $2{ }^{\circ} \mathrm{C}$ ). The performance optimum in Atlantic animals (around $20{ }^{\circ} \mathrm{C}$ ) is located about $3{ }^{\circ} \mathrm{C}$ above lowest habitat summer temperatures $\left(17^{\circ} \mathrm{C}\right)$. Acclimation capacity may reach its upper limits in animals during summer but has not sufficiently been explored in response to shifting summer regimes.

Hummel et al. (1997a) have already shown temperature related variation in genetic traits of Arenicola marina in a latitudinal cline. The present study confirms that not only the capacity to acclimatise characterises the lugworms' tolerance to temperature extremes. Permanent functional differences exist between populations and indicate genetic adaptation to the climate regime. The question arises whether in the course of climate change, the animals would be able to undergo micro-evolutionary adaptation to progressively higher mean and maximum summer temperatures over longer time scales. The present observation of ongoing biogeographical shifts in marine ectotherms and ecosystems rather suggests that the time scale of warming trends is too short to allow for evolutionary adaptation to occur. As a perspective, northernmost populations may be replaced by their more southern counterparts. At the same time, southern populations currently existing close their upper thermal limits may become locally extinct.

\section{Acknowledgements}

This work was supported by grants from the Deutsche Forschungsgemeinschaft (Aquashift Po 278/11). The experiments described here comply with the current laws of the country in which they were performed. We would like to thank J. Saphörster for her work in the digging activity experiments. We are very grateful for the generous support by the Biological Stations at Kartesh (White Sea, Russia) and Arcachon (Atlantic, France). Special thanks go to the T. Hirse, B. Klein and R. Wittig for technical support. [SS]

\section{References}

Angilletta Jr., M.J., Niewiarowski, P.H., Navas, C.A., 2002. The evolution of thermal physiology in ectotherms. J. Therm. Biol. 27, 249-268.

Ashworth, J.H., 1904. Arenicola (The lug-worm). Williams \& Norgatf, London. 126 pp.

Berger, V., Dahle, S., Galaktionov, K., Kosobokova, X., Naumov, A., T. R.k., Savinov, V., Savinova, T., 2001. White Sea. Ecology and environment. Derzavets Publisher, St. Petersburg. 157 pp.

Deere, J.A., Chown, S.L., 2006. Testing the beneficial acclimation hypothesis and its alternatives for locomotor performance. Am. Nat. 168, 630-644.

Frederich, M., Pörtner, H.O., 2000. Cardiac and ventilatory performance at critical temperatures in the spider crab, Maja squinado (Decapoda). Am. J. Physiol. 279, R1531-R1538.

Hartmann-Schröder, G., 1971. Annelida, Borstenwürmer, Polychaeta. VEB Gustav Fischer Verlag, Jena. 406-409 pp.

Huey, R.B., Hertz, P.E., 1984. Is a jack-of-all-temperatures a master of none? Evolution 38, 441-444.

Hummel, H., 2003. Geographical patterns of dominant bivalves and a polychaete in Europe: no metapopulations in the marine coastal zone. Helgol. Mar. Res. 56, 247-251.

Hummel, H., Sommer, A., Bogaards, R.H., Pörtner, H.O., 1997a. Variation in genetic traits of the lugworm Arenicola marina: temperature related expression of mitochondrial allozymes? Mar. Ecol. Prog. Ser. 159, 189-195.

Hummel, H., Bogaards, R., Bek, T., Polishchuck, L., Amiard-Triquet, C., Bachelet, G., Desprez, M., Strelkov, P., Sukhotin, A., Naumov, A., Dahle, S., Denisenko, S., Gantsevich, M., Sokolov, K., de Wolf, L., 1997b. Sensitivity to stress in the bivalve Macoma balthica from the most northern (Arctic) to the most southern (French) populations: low sensitivity in Arctic populations because of genetic adaptations? Hydrobiology 355, 127-138.

Ifremer, 2007. Résultats de la surveillance de la qualité du milieu marin littoral. In: Ifremer/RST.LERAR/07.002 (Ed.), Bulletin de la surveillance. Laboratoire Environnement Ressources d'Arcachon, pp. 1-81.

Krogh-Rasmussen, K., Weber, R.E., 1979. Respiratory properties of erythrocruorin (extracellular haemoglobin) in the blood of the annelid Arenicola marina with special reference to the influences of salinity and temperature. Ophelia 18, 151-170.

Krüger, F., 1971. Bau und Leben des Wattwurms Arenicola marina. Helgol. Wiss. Meeresunters. 22, 149-200.
Leroi, A.M., Bennett, A.F., Lenski, R.E., 1994. Temperature acclimation and competitive fitness: an experimental test of the beneficial acclimation assumption. Proc. Natl. Acad. Sci. U. S. A. 91, 1917-1921.

Levent, B.A.T., 1998. Influence of sediment on heavy metal uptake by the polychaete Arenicola marina. Tr. J. Zool. 22, 341-350.

Mark, F.C., Bock, C., Pörtner, H.O., 2002. Oxygen-limited thermal tolerance in Antarctic fish investigated by MRI and ${ }^{31}$ P-MRS. Am. J. Physiol. Regul., Integr. Comp. Physiol 283, R1254-1262.

Melzner, F., Bock, C., Pörtner, H.-O., 2006a. Temperature-dependent oxygen extraction from the ventilatory current and the costs of ventilation in the cephalopod Sepia officinalis. J. Comp. Physiol., B 176, 607-621.

Melzner, F., Bock, C., Pörtner, H.O., 2006b. Critical temperatures in the cephalopod Sepia officinalis investigated using in vivo ${ }^{31} \mathrm{P}$ NMR spectroscopy. J. Exp. Biol. 209, 891-906.

Newell, R., 1969. Effect of fluctuations in temperature on the metabolism of intertidal invertebrates. Am. Zool. 9, 293-307.

Perry, A.L., Low, P.J., Ellis, J.R., Reynolds, J.D., 2005. Climate change and distribution shifts in marine fishes. Science 308, 1912-1915.

Pörtner, H.-O., 2001. Climate change and temperature-dependent biogeography: Oxygen limitation of thermal tolerance in animals. Naturwissenschaften 88 137-146.

Pörtner, H.-O., 2002a. Climate change and temperature dependent biogeography: systemic to molecular hierarchies of thermal tolerance in animals. Comp. Biochem. Physiol. 132A, 739-761.

Pörtner, H.O., 2002b. Physiological basis of temperature dependent biogeography: tradeoffs in muscle design and performance in polar ectotherms. J. Exp. Biol. 205, 2217-2230.

Pörtner, H.-O., 2006. Climate-dependent evolution of Antarctic ectotherms: an integrative analysis. Deep-Sea Res. II 53, 1071-1104.

Pörtner, H.-O., Knust, R., 2007. Climate change affects marine fishes through the oxygen limitation of thermal tolerance. Science 315, 95-97.

Pörtner, H.O., Hardewig, I., Sartoris, F.J., van Dijk, P.L.M., 1998. Energetic aspects of cold adaptation: critical temperatures in metabolic, ionic and acid-base regulation? In: Pörtner, H.O., Playle, R.C. (Eds.), Cold Ocean Physiology. Cambridge University Press, pp. 88-120.

Pörtner, H.O., van Dijk, P.L.M., Hardewig, I., Sommer, A, 2000. Levels of metabolic cold adaptation: tradeoffs in eurythermal and stenothermal ectotherms. In: Davison, W. Williams, C.W. (Eds.), Antarctic Ecosystems: Models for a wider understanding. Caxton Press, Christchurch, New Zealand, pp. 109-122.

Pörtner, H.O., Mark, F.C., Bock, C., 2004. Oxygen limited thermal tolerance in fish? Answers obtained by nuclear magnetic resonance techniques. Respir. Physiol. Neurobiol. 141, 243-260.

Reise, K., Simon, M., Herre, E., 2001. Density-dependent recruitment after winter disturbances on tidal flats by the lugworm Arenicola marina. Helgol. Mar. Res. 55, $161-165$.

Sauriau, P.-G., 1991. Spread of Cyclope neritea (Mollusca: Gastropoda) along the northeastern Atlantic coasts in relation to oyster culture and to climatic fluctuations. Mar. Biol. 109, 299-309.

Savage, N.B., 1976. Burrowing activity in Mercenaria mercenaria (L.) and Spisula solidissima (Dillwyn) as a function of temperature and dissolved oxygen. Mar. Behav. Physiol. 3, 221-234.

Schreck, C.B., 1981. Stress and compensation in teleostean fishes: responses to social and physical factors. Academic Press, London. 295-321 pp.

Sheppard, C., 2004. Sea surface temperature 1871-2099 in 14 cells around the United Kingdom. Mar. Pollut. Bull. 49, 12-16.

Shumway, S.E., Davenport, J., 1977. Some aspects of the physiology of Arenicola marina (Polychaeta) exposed to fluctuating salinities. J. Mar. Biol. Assoc. U.K. 57, 907-924.

Sommer, A.M., Pörtner, H.-O., 2002. Metabolic cold adaptation in the lugworm Arenicola marina: comparison of a North Sea and a White Sea population. Mar. Ecol. Prog. Ser 240, 171-182.

Sommer, A.M., Pörtner, H.O., 2004. Mitochondrial function in seasonal acclimatization versus latitudinal adaptation to cold in the lugworm Arenicola marina (L.). Physiol. Biochem. Zool. 77, 174-186.

Sommer, A., Klein, B., Pörtner, H.O., 1997. Temperature induced anaerobiosis in two populations of the polychaete worm Arenicola marina (L). J. Comp. Physiol., B 167, 25-35.

van Dijk, P.L., Tesch, C., Hardewig, I.I., Pörtner, H.O., 1999. Physiological disturbances at critically high temperatures: a comparison between stenothermal Antarctic and eurythermal temperate eelpouts (Zoarcidae). J. Exp. Biol. 202 (Pt 24), 3611-3621.

Volkenborn, N., 2006. Ecosystem engineering in intertidal sand by the lugworm Are nicola marina. University of Bremen.

Wesenberg-Lund, E., 1953. The zoology of east Greenland. C. A. Reitzel Forlag Kopenhaven.

Wiltshire, K.H., Manly, B.F.J., 2004. The warming trend at Helgoland Roads, North Sea: phytoplankton response. Helgol. Mar. Res. 58, 269-273.

Wittmann, A.C., Schröer, M., Bock, C., Steeger, H.-U., Paul, R.J., Pörtner, H.-O., 2008 Indicators of oxygen and capacity limited thermal tolerance in the lugworm Arenicola marina. Clim. Res. 37, 227-240.

Zenkevitch, L., 1963. Biology of the seas of the U.S.S.R. Allen \& Unwin, London. 179-192 pp.

Zielinski, S., Pörtner, H.O., 1996. Energy metabolism and ATP free-energy change of the intertidal worm Sipunculus nudus below a critical temperature. J. Comp. Physiol., B $166,492-500$. 